PYTHAGORAS: Jurnal Pendidikan Matematika

Volume 11 - Nomor 1, Juni 2016, (1-10)

Available online at: http://journal.uny.ac.id/index.php/pythagoras

\title{
Keefektifan Model PBL dan PjBL Ditinjau dari Prestasi, Kemampuan Berpikir Kritis, dan Motivasi Belajar Matematika Siswa SMP
}

\author{
Esti Rahayu $^{1} *$, H. Hartono ${ }^{2}$ \\ ${ }^{1}$ SMP Negeri 3 Pengadegan. Desa Pasunggingan, Kabupaten Purbalingga, Jawa Tengah, Indonesia \\ ${ }^{2}$ Jurusan Pendidikan Matematika, Universitas Negeri Yogyakarta, Jalan Colombo No. 1, \\ Karangmalang, Yogyakarta 55281, Indonesia. \\ * Korespondensi Penulis. Email: estirahayupriyambudi@gmail.com, Telp: +6281329578355 \\ Received: 13 ${ }^{\text {th }}$ June 2016; Revised: $20^{\text {th }}$ August 2016; Accepted: $1^{\text {st }}$ September 2016
}

\begin{abstract}
Abstrak
Penelitian ini bertujuan untuk mendeskripsikan dan membandingkan keefektifan antara model PBL setting GI dan PjBL setting GI ditinjau dari prestasi belajar, kemampuan berpikir kritis, dan motivasi belajar matematika siswa SMP. Penelitian ini merupakan penelitian eksperimen semu dengan pretest-posttest nonequivalent group design. Populasi penelitian ini adalah seluruh siswa kelas VIII SMPN 3 Pengadegan Kabupaten Purbalingga, sedangkan sampel yang diperoleh melalui pemilihan secara acak yaitu siswa kelas VIII C dan VIII B. Instrumen yang digunakan adalah tes prestasi belajar, tes kemampuan berpikir kritis, dan angket motivasi belajar matematika. Data dianalisis secara univariat dengan statistik uji one sample t-test untuk mengetahui keefektifan model pembelajaran, sedangkan data dianalisis secara multivariat dengan statistik uji two group MANOVA untuk membandingkan keefektifan model pembelajaran. Setiap analisis menggunakan taraf signifikansi 5\%. Hasil penelitian menunjukan bahwa model PBL setting GI dan PjBL setting GI efektif dan tidak ada perbedaan keefektifan antara kedua model pembelajaran ditinjau dari prestasi belajar, kemampuan berpikir kritis, dan motivasi belajar matematika.
\end{abstract}

Kata Kunci: model PBL setting GI, model PjBL setting GI, prestasi belajar, kemampuan berpikir kritis, dan motivasi belajar.

\section{The Effectiveness of PBL and PjBL Models in Term of Achievement, Critical Thinking Skills, and Motivation in Mathematics Learning of SMP Students}

\begin{abstract}
This study aimed to describe and to compare the effectiveness of PBL model in the setting of GI and PjBL model in the setting of GI in term of learning achievement, critical thinking skills, and motivation in mathematics learning of SMP students. This study was a quasi-experimental research employing the pretest-posttest nonequivalent group design. The research population comprised all students in grade VIII of SMPN 3 Pengadegan Purbalingga. The Samples were students of class VIII $C$ and $D$ were selected randomly from the population.. The data collecting instruments were a test of learning achievement, a test of critical thinking skills, and a questionnaire of motivation in mathematics learning. The data were analyzed using the univariatetechnique with the one sample $t$ test to determine the effectiveness of learning models, while to compare the effectiveness of learning models, the data were analyzed using the multivariate technique with the two groups MANOVA. Each analysis was done at the significance level of 5\%. The results of the study show that the PBL and PjBL models in the setting of GI is effective and there is no difference the effectiveness of the two models in term of learning achievement, critical thinking skills, and motivation in mathematics learning.
\end{abstract}

Keywords: PBL model in the setting of GI, PjBL model in the setting of GI, learning achievement, critical thinking skills, and learning motivation.

How to Cite: Rahayu, E., \& Hartono, H. (2016). Keefektifan model PBL dan PjBL ditinjau dari prestasi, kemampuan berpikir kritis, dan motivasi belajar matematika siswa SMP. PYTHAGORAS: Jurnal Pendidikan Matematika, 11(1), 1-10. doi:http://dx.doi.org/10.21831/pg.v11i1.9629

Permalink/DOI: http://dx.doi.org/10.21831/pg.v11i1.9629 


\section{PENDAHULUAN}

Matematika memiliki peran penting dalam kehidupan manusia. Matematika memberikan keterampilan yang tinggi pada seseorang dalam hal daya abstraksi, analisis permasalahan, dan penalaran logika. Matematika berfungsi pula untuk membantu pengkajian alam sekitar. Hasil pengkajian tersebut dapat dikembangkan menjadi teknologi yang bermanfaat bagi kesejahteraan umat manusia. Selain itu, berbagai permasalahan yang timbul dari sektor pertanian, industri, ekonomi, dan kesehatan dapat diselesaikan dengan pendekatan-pendekatan matematis.

Mengingat berbagai peran penting tersebut, sangat disayangkan sekali bahwa pembelajaran matematika di sekolah mendapat tantangan yang tidak mudah. Salah satu tantangan tersebut adalah prestasi belajar matematika yang masih rendah. Prestasi belajar dipengaruhi oleh berbagai faktor. Salah satu faktor yang mempengaruhi prestasi belajar adalah motivasi yang dimiliki siswa (Kurniawan \& Wutsqa, 2014). Motivasi berperan penting dalam membantu perkembangan potensi siswa dalam hidupnya. Motivasi juga memegang peranan penting dalam memberikan semangat belajar. Tanpa memiliki motivasi tertentu, seseorang akan mudah menyerah (putus asa) karena merasa tidak memiliki kepentingan yang harus diperjuangkan. Adanya motivasi belajar dalam diri siswa akan menimbulkan dorongan mental untuk melakukan aktivitas belajar untuk mencapai tujuan.

Akan tetapi sangat disayangkan bahwa pada proses pembelajaran di sekolah seringkali ditemukan siswa yang berhadapan dengan berbagai permasalahan yang menghambat proses pengembangan dirinya. Hal tersebut ditandai dengan munculnya perasaan mudah putus asa dalam menyelesaikan soal matematika, kurang konsentrasi, kurang bersemangat dalam mengikuti pembelajaran, tidak berupaya untuk menyelesaikan tugas dengan baik, tidak percaya diri saat diminta untuk mengerjakan soal di depan kelas, serta memiliki perasaan takut salah dan tegang saat menjawab pertanyaan dari guru. Kondisi-kondisi tersebut berpengaruh terhadap pencapaian hasil belajar.

Selain faktor internal yang disebutkan sebelumnya, era globalisasi yang semakin berkembang pesat juga memiliki dampak bagi siswa, karena permasalahan yang dihadapi semakin kompleks. Hal tersebut membuat siswa harus memiliki kemampuan yang cukup untuk dapat menghadapinya. Kemampuan yang harus dimiliki siswa salah satunya adalah kemampuan berpikir kritis. Kemampuan tersebut merupakan salah satu kompetensi yang juga harus dikuasai siswa dalam pembelajaran matematika. Kemampuan berpikir kritis menjadi penting bila melihat kondisi zaman sekarang, dimana keadaan sangat cepat berubah serta perkembangan teknologi yang semakin pesat dan sangat kompetitif. Proses pembelajaran di kelas diharapkan mampu mempersiapkan siswa untuk memiliki kompetensi tersebut agar siswa dapat memiliki kemampuan memperoleh, mengelola, dan memanfaatkan informasi untuk hidup lebih baik.

Sangat disayangkan bahwa proses pembelajaran matematika di sekolah belum memiliki kontribusi yang maksimal bagi siswa dalam melatih kemampuan berpikir kritis mereka. Siswa jarang dilibatkan dalam mathematical problem solving dan mathematical reasoning. Pembelajaran juga masih berpusat pada guru dimana peran guru lebih dominan dalam proses belajar dan mengajar. Guru memberikan contoh soal beserta langkah-langkah penyelesaian sebelum memberikan latihan. Hal tersebut membuat siswa mengalami kesulitan dalam menerapkan konsep untuk menyelesaikan latihan atau soal dalam bentuk yang lain. Selain itu, siswa belum mampu memberikan penjelasan logis dari langkah penyelesaian soal yang telah mereka kerjakan dan siswa juga masih mengalami kesulitan dalam memilih dan memilah berbagai informasi yang relevan untuk menyelesaikan masalah. Hal ini mengindikasikan bahwa kemampuan berpikir kritis siswa masih rendah.

Siswa pada umumnya senang berinteraksi dengan teman-teman, karena pada hakikatnya mereka adalah makhluk sosial. Berdasarkan hasil beberapa penelitian sebelumnya, Schunk, Pintrich, \& Meece (Eggen \& Khauchak, 2012, p.170) menyatakan bahwa pengerjaan tugastugas yang berpotensi membosankan bisa ditingkatkan dengan mengerjakannya secara berkelompok. Pembelajaran kooperatif dianggap dapat meningkatkan motivasi belajar dan keaktifan siswa dalam kegiatan pembelajaran.

Salah satu tipe pembelajaran kooperatif adalah Group Investigation (Kagan \& Kagan, 2009, p.17.2). Model pembelajaran kooperatif tipe Group Investigation (GI) merupakan model pembelajaran spesialisasi tugas yang memberikan kesempatan pada siswa untuk mengembangkan kreativitas dan produktivitas berpikirnya. Selain itu, proses belajar mengajar dalam setting pembelajaran kooperatif tipe GI berpe- 
ngaruh terhadap prestasi belajar siswa (Fahrurrozi \& Mahmudi, 2014, p. 1). Melalui investigasi matematika, siswa secara aktif mengkonstruksi atau merekonstruksi kembali pengetahuannya serta mampu mengaplikasikannya dalam penyelesaian masalah. Terdapat enam langkah dalam GI menurut Kagan \& Kagan (2009, p.17.9), Sharan \& Sharan (Arends \& Kilcher, 2010, p.316), dan Slavin (1995, p.113), yaitu mengidentifikasi topik dan pengorganisasian siswa dalam kelompok penelitian, perencanaan, investigasi (penyelidikan), menyiapkan laporan akhir, mempresentasikan laporan akhir, dan evaluasi.

Salah satu materi yang harus dipelajari oleh siswa Sekolah Menengah Pertama adalah Geometri. Pada kenyataannya di sekolah, siswa masih mengalami kesulitan dalam materi ini. Prestasi belajar materi geometri siswa masih rendah. Permasalahan geometri dapat didekati dengan beberapa cara, yaitu dengan cara diujicobakan, dipraktikan secara langsung dimana permasalahan diselesaikan dengan mengukur, dan menghitung (French, 2004, p.2).

Senada dengan pendapat tersebut, terdapat beberapa model pembelajaran yang sesuai dengan tujuan pembelajaran geometri sekaligus juga model pembelajaran yang berpusat pada siswa (student centered). Model pembelajaran tersebut adalah model Problem-Based Learning (PBL) dan Project-Based Learning (PjBL). Barrows (Barrett, 2005, p.14) menyatakan bahwa PBL merupakan pembelajaran yang dihasilkan dari proses bekerja untuk memahami penyelesaian masalah. Selanjutnya Savery (2006, p.12) menyatakan bahwa PBL adalah pendekatan pembelajaran berpusat pada siswa yang memberdayakan siswa untuk melakukan penyelidikan, mengintegrasikan teori beserta praktek, dan menerapkan pengetahuan serta keterampilan untuk mengembangkan solusi yang tepat bagi masalah yang ditetapkan. Mendukung pendapat tersebut, Arends \& Kilcher (2010, p.326) mengungkapkan bahwa PBL adalah pendekatan yang berpusat pada siswa yang melibatkan siswa dalam penyelidikan pada situasi masalah yang kompleks. Titik awal pembelajaran PBL merupakan masalah yang menarik. Siswa diharapkan dapat mencari solusi realistis dari masalah dunia nyata. Selanjutnya Scot dan Laura (Eggen \& Kauchak, 2012, p.307) menyatakan bahwa PBL memiliki tiga karakteristik, yaitu berfokus pada penyelesaian masalah, siswa bertanggung jawab dalam menyelesaikan masalah, dan guru mendukung proses penyelesaian masalah oleh siswa.
Selain itu, hasil penelitian Farhan \& Retnawati (2014) menunjukkan bahwa penerapan PBL dalam pembelajaran matematika efektif ditinjau dari prestasi dan motivasi belajar siswa. Berdasarkan uraian tersebut dapat disimpulkan bahwa PBL efektif diterapkan dalam pembelajaran matematika dan merupakan pembelajaran yang berpusat pada siswa, karena siswa terlibat secara aktif dalam kegiatan penyelesaian masalah.

Model pembelajaran selanjutnya yang juga berpusat pada siswa adalah adalah PjBL. Holbrook (Capraro, Capraro, \& Morgan, 2013, p.50) mendefinisikan PjBL merupakan model untuk kegiatan kelas yang berpusat pada siswa, interdisipliner dan terintegrasi dengan isu-isu dan praktek dunia nyata. Interdisipliner adalah keterlibatan secara sadar dan integrasi beberapa disiplin akademis dan metode untuk mempelajari masalah atau proyek sentral. Menurut Kose (Chang, Wong \& Chang, 2011, p.266), pembelajaran berbasis proyek merupakan pembelajaran yang melatih siswa untuk menggunakan pengetahuan yang diperoleh, keterampilan, dan sikap untuk menyelesaikan masalah dan beradaptasi dengan keadaan yang tidak terduga dalam kehidupan nyata. Senada dengan hal tersebut, Aiedah \& Audrey (2012, p.38) menyatakan bahwa pembelajaran berbasis proyek merupakan penugasan kompleks dengan memberikan pertanyaan berupa tantangan atau permasalahan yang melibatkan siswa untuk mendesain, menyelesaikan masalah, dan melakukan kegiatan penyelidikan.

Berdasarkan uraian tersebut, dapat disimpulkan bahwa pembelajaran berbasis proyek adalah model pembelajaran yang memberdayakan siswa untuk mencapai konten pengetahuan mereka sendiri melalui kegiatan penugasan kompleks dan pada akhirnya siswa menghasilkan produk karya siswa bernilai dan realistik. Pada PjBL siswa belajar secara mandiri dan terlibat aktif dalam penyelesaian masalah dan penyelidikan. Berbagai langkah dalam pembelajaran PjBL pada setting pembelajaran kooperatif tipe GI dalam penelitian ini yaitu dimulai dengan mengatur siswa ke dalam kelompok, menetapkan tema tugas/proyek, membuat desain proyek, membuat jadwal pelaksanaan proyek, mengumpulkan informasi, melaksanakan penyelidikan atau investigasi, menyiapkan laporan, mempresentasikan laporan, dan evaluasi.

Terkait dengan permasalahan dan solusi yang diajukan, maka tujuan penelitian ini adalah untuk mendeskripsikan keefektifan model PBL dan $\mathrm{PjBL}$ setting GI serta untuk mengetahui 
model manakah yang lebih efektif digunakan dari kedua model pembelajaran yang menjadi fokus dalam penelitian ini.

\section{METODE}

Jenis penelitian ini adalah penelitian eksperimen semu (quasi experiment) yang dilaksanakan di SMPN 3 Pengadegan Kabupaten Purbalingga, Provinsi Jawa Tengah. Pengambilan data dilaksanakan pada semester genap tahun pelajaran 2014/2015 pada materi Geometri Ruang Sisi Datar pada 16 Maret sampai 27 April 2015. Populasi dalam penelitian ini adalah seluruh siswa kelas VIII SMP Negeri 3 Pengadegan yang terdiri atas 3 kelas dengan jumlah keseluruhan 84 siswa. Selanjutnya peneliti memilih dua kelas secara acak sebagai sampel. Sampel penelitian ini adalah kelas VIII C dengan jumlah siswa 28 sebagai kelas eksperimen 1 yang diberi perlakuan model PBL setting GI, sedangkan kelas VIII B dengan jumlah siswa 26 merupakan kelas eksperimen 2 yang diberi perlakuan model PjBL setting GI. Desain penelitian dalam penelitian ini adalah pretest-posttest non equivalent group design, dimana variabel terikat diukur dua kali yaitu pada saat sebelum dan setelah perlakuan diberikan. Secara skematis, desain eksperimen dalam penelitian ini dapat dilihat pada Gambar 1.
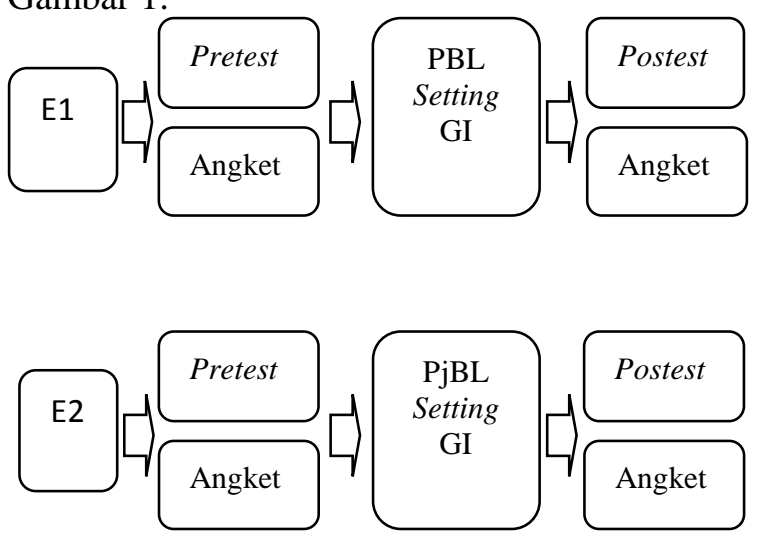

Gambar 1. Diagram Desain Penelitian

Keterangan:

E1: kelas eksperimen 1

E2: kelas eksperimen 2

Secara berurutan, teknik pengumpulan data yang digunakan dalam penelitian ini yaitu, (1) memberikan angket motivasi belajar matematika kepada siswa untuk diisi sebelum melakukan pretest, (2) melakukan pretsest kemampuan berpikir kritis dan prestasi belajar matematika sebelum perlakuan, (3) memberikan angket motivasi belajar matematika kepada siswa untuk diisi sebelum dilakukan postest dan setelah perlakuan, dan (4) memberikan postest kemampuan berpikir kritis dan prestasi belajar matematika setelah perlakuan. Instrumen pengumpulan data terdiri atas instrumen tes dan nontes. Instrumen tes terdiri atas instrumen tes prestasi belajar dan kemampuan berpikir kritis. Bentuk instrumen tes prestasi belajar yaitu tes pilihan ganda, yang terdiri atas 25 soal. Bentuk instrumen tes kemampuan berpikir kritis yaitu tes uraian, yang terdiri atas lima soal. Instrumen non tes terdiri atas instrumen angket motivasi belajar matematika yang terdiri atas 30 pernyataan.

Validitas instrumen pada penelitian ini terdiri atas validitas isi dan validitas konstruk. Validitas isi dilakukan pada instrumen tes (prestasi dan kemampuan berpikir kritis) dan non tes (motivasi belajar). Validitas isi diperoleh dengan cara meminta pertimbangan ahli (expert judgment) dan ketiga instrumen tersebut dinyatakan valid. Validitas konstruk dilakukan pada instrumen non tes. Bukti validitas konstruk dapat diperoleh dari data hasil uji coba yang sudah dianalisis dengan analisis faktor dan diperoleh lima faktor.

Koefisien reliabilitas dihitung untuk tes uji coba prestasi belajar, kemampuan berpikir kritis dan motivasi belajar. Estimasi koefisien reliabilitas tes prestasi belajar matematika yang berbentuk pilihan ganda dihitung dengan menggunakan formula KR-20. Formula KR-20 dapat digunakan hanya pada skor tes dikotomi (0 atau 1), yaitu bernilai satu jika jawaban benar dan bernilai nol jika jawaban salah (Ebel \& Frisbie, 1991, p.84). Estimasi koefisien reliabilitas tes kemampuan berpikir kritis, dan motivasi belajar dihitung dengan menggunakan formula alpha Cronbach. Menurut Cronbach (Ebel \& Frisbie, 1991, p.85), koefisien alpha dapat digunakan untuk mengestimasi reliabilitas pengukuran yang memiliki skor selain 0 dan 1 . Koefisien reliabilitas yang diperoleh diinterpretasikan dengan menentukan nilai Standard Error of Measurement (SEM). Hasil estimasi koefisien reliabilitas dan SEM ketiga instrumen dapat dilihat pada Tabel 1.

Tabel 1. Estimasi Reliabilitas Instrumen

\begin{tabular}{lcc}
\hline \multicolumn{1}{c}{ Instrumen } & $\begin{array}{c}\text { Koefisien } \\
\text { Reliabilitas }\end{array}$ & SEM \\
\hline Prestasi Belajar & 0,71 & 1,90 \\
Kemampuan Berpikir Kritis & 0,75 & 1,84 \\
Motivasi Belajar & 0,71 & 5,16 \\
\hline
\end{tabular}

Data prestasi belajar diperoleh melalui pengukuran menggunakan instrumen tes yang 
berbentuk pilihan ganda, sedangkan data tentang kemampuan berpikir kritis diperoleh melalui pengukuran dengan instrumen tes yang berbentuk essay yang berjumlah lima butir soal. Selanjutnya, skor yang diperoleh dikonversi menjadi nilai dengan rentang 0 s.d. 100. Skor tersebut kemudian digolongkan berdasarkan Kriteria Ketuntasan Minimal (KKM) yang telah ditetapkan di sekolah untuk pelajaran matematika kelas VIII, yaitu 70 .

Selanjutnya data motivasi belajar matematika diperoleh dengan menggunakan instrumen non tes yang berbentuk angket dengan skala Likert. untuk menentukan kriteria variabel motivasi belajar digunakan klasifikasi berdasarkan rata-rata $(\mathrm{M})$ dan standar deviasi (S). $\mathrm{M}=$ $(30+150) / 2=90$ dan $S=(150-30) / 6=20$. Kategori hasil pengukuran menggunakan kriteria yang dikembangkan oleh Azwar (2014, p.163) dapat dilihat pada Tabel 2 .

Tabel 2. Kategori Motivasi Belajar Matematika

\begin{tabular}{cl}
\hline Skor $(\mathbf{X})$ & Kategori Motivasi \\
\hline $121-150$ & Sangat tinggi \\
$101-120$ & Tinggi \\
$81-100$ & Sedang \\
$61-80$ & Rendah \\
$30-60$ & Sangat rendah \\
\hline
\end{tabular}

Pengukuran keefektifan model PBL setting GI dan PjBL setting GI terhadap masingmasing variabel, yaitu prestasi belajar, kemampuan berpikir kritis, dan motivasi belajar menggunakan statistik uji one sample t-test, sedangkan untuk menyelidiki perbedaaan keefektifan model PBL setting GI dan PjBL setting GI ditinjau dari prestasi belajar, kemampuan berpikir kritis, dan motivasi belajar dilakukan dengan uji multivariat, yaitu satistik uji two-group MANOVA dengan asumsi yang harus dipenuhi yaitu normalitas multivariat dan homogenitas matriks kovarian. Kedua pengujian tersebut dilakukan dengan bantuan program SPSS 22 dan kriteria pengambilan keputusan diambil pada taraf signifikansi 5\%.

Pemeriksaan asumsi normalitas multivariat digunakan kriteria $\chi^{2}$, yaitu bila sekitar $50 \%$ nilai $d_{i}^{2}$ lebih kecil dari $\chi_{0,5(p)}^{2}$ maka dapat dikatakan bahwa data populasi berdistribusi normal multivariat (Jhonson \& Wichern, 2007, p.183). Selanjutnya uji Box- $M$ digunakan untuk mengetahui homogenitas matriks kovarians dua kelompok dengan tiga variabel terikat secara simultan (Stevens, 2009, p.230). Pengujian tersebut juga dilakukan dengan bantuan program SPSS 22 dan kriteria pengambilan keputusan diambil pada taraf signifikansi $5 \%$.

\section{HASIL DAN PEMBAHASAN}

Data hasil tes prestasi belajar matematika yang akan dideskripsikan terdiri atas data pretest dan posttest. Pretest merupakan tes yang diberikan pada kedua kelompok yang diteliti, yaitu kelompok PBL setting GI dan kelompok PjBL setting GI sebelum perlakuan dan dilaksanakan untuk mengetahui kemampuan awal siswa pada materi bangun ruang sisi datar. Posttest merupakan tes yang diberikan kepada kedua kelompok setelah perlakuan dilaksanakan dan tes ini dilaksanakan untuk mengetahui prestasi belajar matematika siswa setelah perlakuan. Hasil tes prestasi belajar matematika pada kedua kelompok sebelum perlakuan dan setelah perlakuan dapat dilihat pada Tabel 3 .

Tabel 3. Deskripsi Data Prestasi Belajar

\begin{tabular}{lcccc}
\hline & \multicolumn{2}{c}{ PBL - GI } & \multicolumn{2}{c}{ PjBL - GI } \\
\cline { 2 - 5 } & Pre & Post & Pre & Post \\
\hline Rata-rata & 32,86 & 83,57 & 31,38 & 78,15 \\
SD & 15,29 & 12,66 & 15,54 & 15,10 \\
Max & 56,00 & 100 & 56,00 & 100 \\
Min & 4,00 & 56,00 & 4,00 & 44,00 \\
\hline
\end{tabular}

Selain data yang telah dijabarkan pada Tabel 3, data hasil tes kemampuan berpikir kritis matematika juga dideskripsikan atas data pretest dan posttest. Pretest dilaksanakan untuk mengetahui kemampuan berpikir kritis siswa sebelum perlakuan pada materi bangun ruang sisi datar, sedangkan Posttest dilaksanakan untuk mengetahui kemampuan berpikir kritis matematika siswa setelah perlakuan. Hasil tes kemampuan berpikir kritis matematika pada kedua kelompok sebelum perlakuan dan setelah perlakuan disajikan pada Tabel 4.

Tabel 4. Deskripsi Data Kemampuan Berpikir Kritis

\begin{tabular}{lcccc}
\hline & \multicolumn{2}{c}{ PBL - GI } & \multicolumn{2}{c}{ PjBL - GI } \\
\cline { 2 - 5 } & Pre & Post & Pre & Post \\
\hline Rata-rata & 30,87 & 81,11 & 31,71 & 75,73 \\
SD & 7,47 & 12,37 & 5,35 & 10,50 \\
Max & 46,67 & 97,78 & 40,00 & 95,56 \\
Min & 17,78 & 55,56 & 17,78 & 53,33 \\
\hline
\end{tabular}

Data selanjutnya yang dikumpulkan oleh peneliti adalah data motivasi belajar matematika siswa pada saat sebelum dan setelah perlakuan. Data yang diperoleh kemudian dianalisis dengan statistik deskriptif. Deskripsi data hasil angket motivasi belajar matematika siswa sebelum dan setelah perlakuan disajikan pada Tabel 5. 
Tabel 5. Deskripsi Data Motivasi Belajar

\begin{tabular}{lcccc}
\hline & \multicolumn{2}{c}{ PBL - GI } & \multicolumn{2}{c}{ PjBL - GI } \\
\cline { 2 - 5 } & Pre & Post & Pre & Post \\
\hline Rata-rata & 99,25 & 115,89 & 97,42 & 116,65 \\
SD & 10,16 & 8,56 & 10,87 & 9,35 \\
Max & 119,00 & 130,00 & 121,00 & 137,00 \\
Min & 78,00 & 98,00 & 80,00 & 99,00 \\
Kriteria & Sedang & tinggi & sedang & tinggi \\
\hline
\end{tabular}

Setelah keseluruhan data terkumpul, peneliti melaksanakan analisis terhadap data-data tersebut. Analisis data yang dilakukan dalam penelitian ini meliputi uji kondisi awal dan uji kondisi akhir. Uji kondisi awal dilaksanakan untuk menguji perbedaan kemampuan awal antara kelompok PBL setting GI dan kelompok PjBL setting GI ditinjau dari prestasi belajar, kemampuan berpikir kritis, dan motivasi belajar matematika. Uji kondisi akhir dilaksanakan untuk menguji keefektifan model PBL setting GI dan PjBL setting GI ditinjau dari masing-masing aspek yang telah disebutkan sebelumnya, serta untuk menguji model manakah diantara kedua model pembelajaran tersebut yang lebih efektif, ditinjau ketiga aspek yang telah disebutkan sebelumnya. Sebelum data dianalisis menggunakan statistik uji two-group MANOVA, asumsi prasyarat pengujian tersebut harus harus terpenuhi. Kedua asumsi tersebut adalah normalitas multivariat dan homogenitas matriks kovarians dari kedua kelompok. Hasil uji normalitas multivariat sebelum dan setelah perlakuan dapat dilihat pada Tabel 6 .

Tabel 6. Hasil Uji Normalitas Multivariat Sebelum dan Setelah Perlakuan

\begin{tabular}{llc}
\hline \multirow{2}{*}{ Kelompok } & \multicolumn{2}{c}{ Persentase $\boldsymbol{d}_{\boldsymbol{i}}^{2}<\chi_{\mathbf{0}, \mathbf{5}(\mathbf{3})}$} \\
\cline { 2 - 3 } & \multicolumn{1}{c}{ Pretest } & Posttest \\
\hline PBL-GI & $46,43 \%$ & $50,00 \%$ \\
PjBL-GI & $50,00 \%$ & $50,00 \%$ \\
\hline
\end{tabular}

Berdasarkan Tabel 6, diperoleh hasil bahwa pada kelompok PBL setting GI sebelum perlakuan diperoleh persentase sebesar $46,43 \%$ nilai $d_{i}^{2}<\chi_{0,5(3)}^{2}$. Persentase tersebut memiliki nilai yang tidak jauh dari $50 \%$ sehingga dapat disimpulkan bahwa data berasal dari populasi yang berdistribusi normal. Uji normalitas multivariat data pada kelompok PjBL setting GI sebelum perlakuan diperoleh persentase sebesar 50\% nilai $d_{i}^{2}<\chi_{0,5(3)}^{2}$. Berdasarkan hasil perhitungan tersebut dapat disimpulkan pula bahwa data berasal dari populasi yang berdistribusi normal. Selanjutnya pada kelompok PBL dan PjBL setting GI yang telah diberikan perlakuan, diperoleh persentase masing-masing sebesar 50\% nilai $d_{i}^{2}<\chi_{0,5(3)}^{2}$. Berdasarkan hasil perhitungan tersebut dapat disimpulkan pula bahwa data berasal dari populasi yang berdistribusi normal.

Uji yang dilaksanakan selanjutnya adalah uji $B o x-M$ yang digunakan untuk mengetahui homogenitas matriks kovarians dua kelompok dengan tiga variabel terikat secara simultan. Hasil uji Box's $M$ sebelum dan setelah perlakuan dapat dilihat pada Tabel 7.

Tabel 7. Hasi Uji Box's-M Sebelum dan Setelah Perlakuan

\begin{tabular}{ccc}
\hline & Pretest & Posttest \\
\hline Box's M & 8,678 & 5,080 \\
F & 1,355 & 0,793 \\
Sig. & 0,229 & 0,575 \\
\hline
\end{tabular}

Berdasarkan hasil uji Box's $M$ sebelum dan setelah perlakuan, masing-masing diperoleh nilai signifikansi sebesar 0,229 dan 0,575. Kedua hasil perhitungan tersebut bernilai lebih dari 0,05 , sehingga dapat disimpulkan bahwa matriks kovarians pada kedua kelompok sebelum dan setelah perlakuan adalah homogen.

Selanjutnya, uji MANOVA dilakukan baik pada data yang diperoleh sebelum dan setelah perlakuan karena asumsi normalitas multivariat dan homogenitas matriks kovarian terpenuhi. Analisis menggunakan bantuan program SPSS 22. Hasil uji MANOVA sebelum dan setelah perlakuan dapat dilihat pada Tabel 8 .

Tabel 8. Hasil Uji MANOVA (Hotelling's Trace) Sebelum dan Setelah Perlakuan

\begin{tabular}{ccc}
\hline & Pretest & Posttest \\
\hline F & 0,337 & 1,316 \\
Sig. & 0,799 & 0,280 \\
\hline
\end{tabular}

Berdasarkan hasil uji MANOVA sebelum perlakuan, angka signifikansi yang diperoleh adalah 0,799. Nilai signifikansi tersebut lebih dari 0,05 . Hal ini menunjukkan bahwa kedua kelompok memiliki mean kelompok yang sama. Hal tersebut memiliki makna bahwa sebelum perlakuan dilakukan, peneliti telah memastikan bahwa kedua kelompok berasal kelompokkelompok yang memiliki mean yang sama secara multivariat atau tidak terdapat perbedaan kemampuan awal antara kelompok PBL setting GI dan PjBL setting GI. Sedangkan hasil uji MANOVA setelah perlakuan menunjukkan angka signifikansi 0,280 . Nilai signifikansi tersebut lebih dari 0,05. Hal ini menunjukkan bahwa setelah diberikan perlakuan, kedua kelompok tidak memiliki perbedaan mean multivariat atau 


\section{Pythagoras, 11 (1), Juni 2016 - 7}

Esti Rahayu, H. Hartono

tidak terdapat perbedaan keefektifan antara kelompok PBL setting GI dan PjBL setting GI. Keefektifan yang dimaksud adalah keefektifan ditinjau dari variabel prestasi belajar, kemampuan berpikir kritis, dan motivasi belajar. Untuk mengetahui keefektifan masing-masing kelompok belajar, dilakukan uji one sample t-test. Adapau hasil uji one sample t-test dapat dilihat pada Tabel 9.

Tabel 9. Uji One Sample t-test Kelompok PBL Setting GI dan PjBL Setting GI

\begin{tabular}{llcc}
\hline Kelompok & \multicolumn{1}{c}{ Variabel } & $\mathrm{t}$ & Sig. \\
\hline PBL- GI & Prestasi belajar & 5,67 & 0,00 \\
& Kemampuan Berpikir & 4,75 & 0,00 \\
& Kritis & & \\
& Motivasi Belajar & 9,21 & 0,00 \\
PjBL - & Prestasi Belajar & 2,75 & 0,01 \\
GI & Kemampuan Berpikir & 2,78 & 0,01 \\
& Kritis & & \\
& Motivasi belajar & 8,54 & 0,00 \\
\hline
\end{tabular}

Berdasarkan Tabel 9, diperoleh nilai signifikansi untuk variabel prestasi belajar, kemampuan berpikir kritis, dan motivasi belajar kelompok PBL setting GI dan PjBL setting GI kurang dari 0,05 . Hal ini berarti pembelajaran dengan menggunakan model PBL setting GI dan $\mathrm{PjBL}$ setting GI efektif ditinjau dari prestasi belajar, kemampuan berpikir kritis, dan motivasi belajar matematika.

Hasil analisis menunjukkan bahwa penerapan model pembelajaran PBL setting GI pada kelompok eksperimen pertama, berdasarkan kriteria keputusan pada $t$-test one sample, efektif ditinjau dari prestasi belajar, kemampuan berpikir kritis, dan motivasi belajar matematika. Hal ini disebabkan langkah-langkah atau sintak dalam pembelajaran PBL setting GI yang telah ditentukan sudah terlaksana. Dalam pembelajaran matematika dengan menerapkan model PBL setting GI, siswa aktif terlibat dalam penyelidikan/investigasi dalam kerja kelompok untuk menyelesaikan suatu masalah yang diberikan kemudian mereka mampu mempresentasikan temuan mereka kepada anggota kelompok yang lain. Kegiatan investigasi dan penyelesaian masalah dalam kelompok membantu siswa belajar lebih mendalam dan mengarahkan siswa pada pemahaman yang lebih luas, sehingga tujuan pembelajaran yang telah ditetapkan dapat tercapai. Hal ini menyebabkan model PBL setting GI efektif ditinjau dari prestasi belajar matematika siswa.

Selain itu, kerjasama dalam menyelesaikan masalah sangat dibutuhkan karena setiap anggota kelompok harus memahami langkahlangkah penyelesaiannya. Hal tersebut membuat setiap siswa berusaha dengan sungguh-sungguh agar dapat menguasai dan memahami cara penyelesaian masalah yang diberikan serta mampu memberikan alasan logis atas penyelesaian masalah tersebut. Dalam proses penyelesaian masalah, bukan hanya hasil akhir yang diperhatikan akan tetapi proses penyelesaian masalah menjadi bagian yang penting. Siswa dibiasakan untuk menggunakan kemampuan berpikir kritisnya dalam menyelesaikan permasalahan. Hal ini yang menyebabkan model PBL setting GI efektif ditinjau dari kemampuan berpikir kritis.

Senada dengan uraian tersebut, kerjasama dalam kelompok PBL setting GI juga membuat siswa tidak mudah merasa bosan dalam pembelajaran, karena siswa dapat berdiskusi dengan sesama anggota kelompoknya untuk menyelesaikan masalah. Siswa lebih termotivasi dalam mengikuti pembelajaran karena fokus dalam penyelesaian masalah sehingga waktu pembelajaran terasa menjadi lebih singkat. Hal ini menyebabkan model PBL setting GI efektif ditinjau dari motivasi belajar matematika siswa.

Berbeda dengan kedua jenis pembelajaran sebelumnya, pada pembelajaran konvensional, para siswa hanya pasif menerima materi yang diberikan oleh guru. Sedangkan dalam pembelajaran PBL setting GI, siswa dituntut untuk aktif menggali pengetahuan melalui kegiatan investigasi dan penyelesaian masalah. Hal ini disebabkan dalam pembelajaran matematika dengan menerapkan model PBL setting GI dirancang untuk membantu siswa untuk mengembangkan keterampilan berpikir, keterampilan menyelesaikan masalah dan keterampilan intelektualnya serta menjadikan siswa menjadi pembelajar yang mandiri. Pembelajaran matematika yang menerapkan model pembelajaran PBL setting GI efektif ditinjau dari prestasi belajar, kemampuan berpikir kritis dan motivasi belajar matematika. Pernyataan tersebut sejalan dengan kajian teori dan hasil penelitian yang telah dilakukan sebelumnya, yaitu penelitian yang dilakukan oleh Farhan \& Retnawati (2014) yang menyatakan bahwa PBL efektif ditinjau dari prestasi dan motivasi belajar matematika. Mendukung hasil penelitian tersebut, Sholikhah (2014) berdasarkan hasil penelitian yang telah dilakukannya juga mengemukakan bahwa PBL efektif ditinjau dari kemampuan berpikir kritis. Senada dengan kedua pendapat sebelumnya tersebut, Baki, et al (2010, p.183) juga menyatakan bahwa siswa yang diajar dengan menerapkan pembelajaran 


\section{Pythagoras, 11 (1), Juni 2016 - 8}

Esti Rahayu, H. Hartono

kooperatif Group Investigation lebih senang bekerja dalam kelompok serta meningkatkan sikap kerjasama.

Selain hasil analisis penerapan model PBL, hasil analisis penerapan model pembelajaran PjBL setting GI pada kelompok eksperimen kedua, berdasarkan kriteria keputusan pada t-test one sample, pembelajaran $\mathrm{PjBL}$ setting GI juga efektif ditinjau dari prestasi belajar, kemampuan berpikir kritis, dan motivasi belajar matematika. Hal ini disebabkan tahapan-tahapan atau sintaks dalam model pembelajaran $\mathrm{PjBL}$ setting GI secara keseluruhan sudah terlaksana dengan baik. Dalam pembelajaran matematika yang menerapkan model PjBL setting GI siswa merencanakan, menyelesaikan dan pada akhirnya menghasilkan suatu produk. Melalui kegiatan penyelidikan ini siswa terlibat langsung dalam menemukan konsep-konsep geometri, sehingga siswa lebih memahami konsep-konsep goemetri yang bersifat abstrak menjadi lebih nyata. Siswa tidak hanya sekedar menghafal rumus-rumus dalam geometri ruang sisi datar tetapi juga mengetahui darimana rumus-rumus tersebut diturunkan, sehingga siswa dapat mencapai tujuan pembelajaran yang telah ditetapkan. Hal ini menyebabkan model PjBL setting GI efektif ditinjau dari prestasi belajar matematika siswa.

Selain uraian tersebut, konsep-konsep yang siswa peroleh dari kegiatan penyelidikan dan proyek, diterapkan untuk menyelesaikan masalah sehingga siswa memperoleh pengalaman yang bermakna dalam memperoleh pengetahuan. Melalui kegiatan proyek dan penyelesaian masalah, siswa dilatih untuk menggunakan kemampuan berpikir kritisnya, yaitu menggunakan keterampilan menginterpretasi, menganalisis, mengevaluasi dan membuat kesimpulan serta mampu menjelaskan argumen. Hal ini menyebabkan model PBL setting GI efektif ditinjau dari kemampuan berpikir kritis.

Mendukung uraian tersebut, dalam pembelajaran PjBL setting GI siswa juga terlibat secara aktif dalam menggali pengetahuan melalui kegiatan proyek dan penyelidikkan dalam kelompok, kemudian mempresentasikan hasil proyek baik secara lisan maupun tertulis. Masing-masing anggota kelompok membuat laporan hasil proyek secara mandiri, sehingga setiap siswa berusaha untuk terlibat aktif dalam kerja kelompok. Aktivitas yang terbangun diantara kelompok untuk menyelesaikan proyek berlangsung penuh semangat, siswa melalui pengamatan terlihat menikmati cara belajar yang dikembangkan berdasarkan langkah-langkah pembelajaran model PjBL setting GI. Hal ini menyebabkan model PBL setting GI efektif ditinjau dari motivasi belajar matematika siswa.

Memperkuat hasil penelitian tersebut, terdapat beberapa ahli yang telah melakukan penelitian dengan hasil yang senada. Penelitian yang dilakukan Filippatou \& Kaldi (2010) menunjukkan bahwa pembelajaran berbasis proyek efektif ditinjau dari kemampuan akademik dan motivasi belajar. Hasil penelitian Imawan (2015) menunjukkan bahwa penerapan model PjBL efektif ditinjau dari prestasi belajar, kepercayaan diri, dan keterampilan berpikir kritis. Selain itu, penelitian yang dilakukan oleh Quigley (2010) juga menunjukkan bahwa pembelajaran dengan menerapkan strategi project-based learning dan strategi campuran kolaboratif-investigasi dapat meningkatkan prestasi belajar matematika siswa.

Dari uraian tersebut telah dijelaskan bahwa faktor yang menjadi penyebab efektifnya kedua model pembelajaran tersebut ditinjau dari aspek prestasi belajar, kemampuan berpikir kritis, dan motivasi belajar matematika adalah karena kedua model memiliki kelebihan dan ciri khas masing-masing. Selain itu, karakteristik materi geometri cocok jika diterapkan pada model pembelajaran PBL setting GI maupun PjBL setting GI. Hal ini didasarkan pada tingkattingkat pemikiran geometris Van Hiele, dimana untuk kelas VIII SMP masuk kategori level 1 dan 2. Kegiatan pengajaran dalam geometri yang tepat untuk level 1 yaitu lebih fokus pada sifat-sifat bentuk daripada identifikasi sederhana (sebagai contoh pada bangun kubus memiliki 6 bidang sisi yang berbentuk persegi yang kongruen) dan menerapkan seluruh ide-ide ke seluruh kelompok bentuk daripada model-model bentuk per individu (sebagai contoh kubus merupakan prisma segiempat beraturan). Sedangkan untuk level 2, kegiatan pengajaran dalam geometri yang dilakukan yaitu mendorong pengujian hipotesis atau perkiraan, memeriksa sifat-sifat bentuk untuk menentukan kondisi yang diperlukan untuk berbagai bentuk atau konsep dan mendorong siswa untuk mencari bukti-bukti informal. Dengan melihat tingkat-tingkat pemikiran geometris baik pada level 1 maupun level 2 , keduanya cocok bila disesuaikan dengan langkah-langkah pembelajaran pada model PBL setting GI dan PjBL setting GI. Dengan demikian dapat disimpulkan bahwa kedua model pembelajaran PBL setting GI dan PjBL setting GI efektif ditinjau dari prestasi belajar, kemampuan berpikir kritis dan motivasi belajar matematika 
siswa kelas VIII di SMP Negeri 3 Pengadegan pada materi geometri ruang.

Hasil analisis selanjutnya, MANOVA, menunjukkan bahwa tidak terdapat perbedaan keefektifan yang signifikan antara model PBL setting GI dan PjBL setting GI ditinjau dari prestasi belajar, kemampuan berpikir kritis, dan motivasi belajar matematika. Tidak terdapatnya perbedaan antara model pembelajaran PBL setting GI dan PjBL setting GI diduga juga disebabkan pembelajaran matematika pada kelompok eksperimen 1 (Kelas VIII C) dan kelompok eksperimen 2 (Kelas VIII B) sama-sama disetting dengan pembelajaran kooperatif tipe GI, dimana dalam pembelajaran matematika di kedua kelompok siswa dituntut untuk secara aktif menemukan pengetahuan mereka melalui kegiatan diskusi dalam kelompok. Selain itu, masingmasing model pembelajaran tersebut mempunyai kelebihan tersendiri. PBL setting GI menghadapkan siswa pada masalah nyata, masalah tersebut berfungsi sebagai stimulus pembelajaran karena memberi kesempatan siswa berpikir dalam proses penyelidikkan masalah, siswa tidak hanya mengingat konsep-konsep yang dipelajarinya tetapi juga diberi kesempatan untuk memahami penggunaannya. Sedangkan pada pembelajaran dengan model PjBL setting GI, siswa dihadapkan pada proyek yang pada akhirnya siswa harus menghasilkan suatu produk. Melalui kegiatan proyek dan penyelidikkan tersebut, siswa lebih memahami konsep-konsep geometri yang bersifat abstrak menjadi lebih nyata. Berdasarkan perbandingan model pembelajaran PBL setting GI dan PjBL setting GI secara umum mempunyai kesamaan dilihat dari tujuan kognitif, tujuan sosial, struktur kelompok, dan pemilihan topik pelajaran.

Walaupun tidak terdapat perbedaan keefektifan antara model PBL setting GI dan PjBL setting GI, keduanya efektif dalam pembelajaran matematika khususnya untuk materi geometri ruang sisi datar. Efektif yang dimaksudkan adalah efektif ditinjau dari prestasi belajar, kemampuan berpikir kritis dan motivasi belajar matematika. Dengan demikian baik model pembelajaran PBL setting GI dan model PjBL setting GI sebagai model pembelajaran yang dapat meningkatkan prestasi belajar, kemampuan berpikir kritis, dan motivasi belajar matematika.

\section{SIMPULAN DAN SARAN}

\section{Simpulan}

Berdasarkan hasil penelitian, dapat disimpulkan bahwa model pembelajaran PBL setting GI dan PjBL setting GI efektif ditinjau dari prestasi belajar, kemampuan berpikir kritis, dan motivasi belajar matematika, namun tidak ada perbedaan keefektifan antara model PBL setting GI dan model PjBL setting GI ditinjau dari prestasi belajar, kemampuan berpikir kritis, dan motivasi belajar matematika.

\section{Saran}

Berdasarkan hasil yang diperoleh, disarankan bagi para peneliti selanjutnya yang akan melakukan penelitian sejenis supaya mempertimbangkan karakteristik materi, serta kebutuhan siswa akan model pembelajaran yang akan diterapkan. Selain itu, dalam pembuatan perangkat pembelajaran seperti RPP dan LKS juga harus memperhatikan antara banyaknya tujuan pembelajaran yang harus dicapai dengan alokasi waktu yang telah ditetapkan. Selain itu, disarankan bagi guru matematika untuk menerapkan model pembelajaran PBL setting GI maupun PjBL setting GI untuk meningkatkan prestasi belajar, kemampuan berpikir kritis, dan motivasi belajar matematika siswa.

\section{DAFTAR PUSTAKA}

Aiedah, A.K, \& Audrey, L. K. C. (2012). Application of project-based learning in student's engagement in malaysian studies and english language. Journal of Interdisciplinary Research In Education, 2 (1), 37-46.

Arends, R. I., \& Kilcher, A. (2010). Teaching for student learning: becoming an accomplished taecher. New York, NY: Routledge.

Azwar, S. (2014). Tes prestasi: fungsi dan pengembangan pengukuran prestasi belajar. Yogyakarta: Pustaka Pelajar Offset.

Baki, A., et.al. (2010). The application of group investigation technique: the views of the teacher and students. Turkish Journal of Computer and Mathematics Education, 1(1), 166-186.

Barrett, T. (2005). Understanding problembased learning. Diakses tanggal 16 Agustus 2014 dari http://www.aishe.org 
Capraro, R. M., Capraro, M. M., \& Morgan, J. R. (2013). Stem project-based learning. Rotterdam, The Netherlands: Sense Publishers

Chang, C. S., Wong, W. T., \& Chang, C. Y. (2011). Integration of project based learning strategy with mobile learning: case study of mangrove wetland ecology exploration project. Tamkang Journal of Science and Engineering, 14 (3), 265 273.

Ebel, R. I. \& Frisbie, D. A.(1991). Essential of educational measurement. $\left(5^{\text {th }} e d\right)$. New Delhi, India: Prentice-Hall, Inc.

Eggen, P \& Kauchak, D. (2012). Strategi dan model pembelajaran: mengajarkan konten dan keterampilan berpikir. (Terjemahan Satrio Wahono). Boston, MA: Pearson Education. (Buku asli diterbitkan tahun 2012).

Fahrurrozi, F., \& Mahmudi, A. (2014). Pengaruh PBM dalam setting pembelajaran kooperatif tipe STAD dan GI terhadap prestasi belajar dan kecerdasan emosional siswa. Jurnal Riset Pendidikan Matematika, 1(1), 1-11. doi:http://dx.doi.org/10.21831/jrpm.v1i1. 2653

Farhan, M., \& Retnawati, H. (2014). Keefektifan PBL dan IBL ditinjau dari prestasi belajar, kemampuan representasi matematis, dan motivasi belajar. Jurnal Riset Pendidikan Matematika, 1(2), 227240. doi:http://dx.doi.org/10.21831/jrpm.v1i2. 2678

Filippatou, D., \& Kaldi, S. (2010). The effectiveness of project-based learning on pupils with learning difficulties regarding academic performance, group work and motivation. International Journal of Special Education, 25 (1), 17-26.

French, D. (2004). Teaching and learning geometry: issues and methods in mathematical education. New York, NY: Continuum International Publishing Group.
Imawan, O. (2015). Perbandingan antara keefektifan model guided discovery learning dan project-based learning pada matakuliah geometri. PYTHAGORAS: Jurnal Pendidikan Matematika, 10(2), 179-188.

doi:http://dx.doi.org/10.21831/pg.v10i2.9 156

Jhonson, R.A., \& Wichern, D.W. (2007). Applied Multivariate Statistical Analysis. Upper Saddle River, NJ: Pearson Prentice Hall.

Kagan, S., \& Kagan, M. (2009). Kagan cooperative learning. San Clemente, CA: Kagan Publishing.

Kurniawan, D., \& Wustqa, D. (2014). Pengaruh perhatian orangtua, motivasi belajar, dan lingkungan sosial terhadap prestasi belajar matematika siswa SMP. Jurnal Riset Pendidikan Matematika, 1(2), 176-187. doi:http://dx.doi.org/10.21831/jrpm.v1i2. 2674

Quigley, D. (2010). Project-based learning and student achievement. Disertasi. Walden University, United States.

Savery, J. R. (2006). Overview of problembased learning: definitions and distinctions. Interdisciplinary Journal of Problem-Based Learning, 1 (1), 9-20.

Slavin, R. E. (1995). Cooperative learning: theory, research, and practice. $\left(2^{\text {nd }} e d.\right)$. Boston, MA: Allyn \& Bacon.

Sholikhah. (2014). Perbandingan keefektifan problem-based learning (PBL) setting model pembelajaran kooperatif tipe numbered head together (NHT) dengan tipe jigsaw pada materi geometri ditinjau dari prestasi belajar matematika, kemampuan berpikir kritis dan disposisi matematis siswa kelas X SMA. Tesis tidak diterbitkan. Universitas Negeri Yogyakarta, Yogyakarta

Stevens, J. P. (2009). Applied multivariate statistic for the social sciences $\left(5^{\text {th }} \mathrm{ed}\right.$.). New York, NY: Taylor and Francis Group 